\title{
REPOSSESSING ISLAM: AFFECTIVE IDENTITY AND ISLAMIC FUNDAMENTALISM IN HANIF KUREISHI
}

\author{
ANDREAS ATHANASIADES \\ University of Cyprus \\ athanasiades.andreas@ucy.ac.cy
}

Received: 28-08-2014

Accepted: 21-12-2014

\begin{abstract}
The present article argues that the processes which seem to have spawned the contemporary generation of British jihadists started in 1980s Britain, when Thatcherite practices led to the rise of racism and the suppression of dissident voices, a by-product of which was the disassociation of Muslim immigrants from the host society. The result was that the next generation of immigrants was much more prone to religious violence, attracted as it was towards the supposedly- stable sense of identity offered by Islamic fundamentalism. The issue of identity of British Muslim immigrants is examined by revisiting Hanif Kureishi's The Black Album (1995), whose narrative representations open up spaces in the British cultural landscape to intentionally include the marginalised and disenfranchised. The hypothesis is that the essentialist choice faced by his characters within the conflictual context generated by the clash of Islamic fundamentalism and sexual liberation is similar to the one diasporic subjects face today. The argument is that the process of thinking about identity in affective terms, based on the theories of the likes of Brian Massumi and Deleuze and Guattari, gestures towards a new way of addressing questions of belonging for diasporic subjects, which can have a profound effect on the perception of issues such as religious fundamentalism and social integration.
\end{abstract}

KEYWORDS: Islamic Fundamentalism; British Muslims; Immigrants; Diasporic Identities; Affect; Desire

RESUMEN La recuperación del islam: la identidad afectiva y el fundamentalismo islámico en la obra de Hanif Kureishi

El presente artículo sostiene que los procesos que parecen haber dado origen a la generación contemporánea de yihadistas británicos se iniciaron en la Gran Bretaña de los años ochenta, época en la que las prácticas tatcherianas condujeron al incremento del racismo y a la supresión de las voces disidentes, lo cual dio como resultado la disociación de los inmigrantes musulmanes de la sociedad que los acogió. En consecuencia, la siguiente generación de inmigrantes mostró una mayor propensión a la violencia religiosa y al, presuntamente estable, sentido de identidad que ofrecía el fundamentalismo islámico. El problema de identidad de los inmigrantes musulmanes británicos se examina mediante una nueva revisión de la obra The Black Album de Hanif Kureishi (1995), cuyas representaciones narrativas abren espacios en el ambiente cultural británico para incluir de manera intencional a los marginados y privados de derechos civiles. La hipótesis consiste en que la elección esencialista a la que se enfrentan los 
personajes dentro del contexto conflictual generado por el choque del fundamentalismo islámico con la liberación sexual es similar a aquella a la que los individuos de la diáspora se enfrentan en la actualidad. El argumento sostiene que el proceso de pensar en la identidad en términos afectivos, basándose en las teorías de los afectos de Brian Massumi y Deleuze y Guattari, muestra una nueva manera de abordar los interrogantes sobre la identidad nacional de los individuos de la diáspora, la cual puede tener un profundo efecto en la percepción de problemas tales como el fundamentalismo religioso y la integración social.

PALABRAS CLAVE: fundamentalismo islámico; musulmanes británicos; inmigrantes; identidades de la diáspora; afecto; deseo

\section{The Affective Nature of Identity}

It seemed to me that [...] younger kids would be interested in what I was interested in: Bhangra music, pop culture, all that stuff. But they had completely rejected all of that, and I was really shocked, because those kids were as English as me. They were born and raised in England, yet they rejected the West. They hated it. Boys from Birmingham were burning books by Muslim writers who were making fun of Islam. This wasn't some ancient tradition. I mean, there are all kinds of liberal ideas in the Muslim tradition, anyway. Pretending that this fundamentalism was the only Islam was definitely a modern thing. A kind of repossession of Islam (Hanif Kureishi, in Amitava, 2001:127-128).

Undeniably, the dynamics of sexual identities in Britain during the last three decades have not been thoroughly examined, especially since the basic contention for addressing questions of belonging has been the issue of race. I argue that such a limited scope for defining identity, especially pertaining to the Muslim South Asian Diaspora in Britain, has led to violent expressions on both sides, what with the emergence of neo-Nazi movements such as the National Front in the 1980s and the religious violence in London in 2005 and today in Syria and Iraq. One of the reasons for such culminations is the inability or unwillingness of the host society to properly understand the complexity and polyvalent nature of identity and sense of belonging in second- and third-generation immigrants in Britain from the 1980s until this very day. It has been argued that the feelings of alienation and disassociation certain diasporic subjects experience today, a situation that reflects that of previous generations of immigrants, has led to a longing for a coherent sense of identity in Islamic fundamentalism, which functions as a refuge for people (Malik, 2009, From Fatwa to Jihad). If we are to interrogate such hegemonic discourses on the formation of identities in Britain then, we would have to move away from seeing race as the only marker for identity, which is the scope of the present article. Instead, I argue, we can turn towards the affective nature of identity and towards 
a re-imagining of desire. Such a re-imagining functions as a means of disrupting ongoing discussions on identity and the nation, which is what the British-born author Hanif Kureishi -himself a second-generation immigrant from the Indian subcontinentdid in his fiction on the very subject of fundamentalism some 20 years ago. A need to retrospectively examine his characters' affective choices arises then (like Shahid in his 1995 novel The Black Album), vis-a-vis fundamentalism and sexual liberation, as their dilemmas reflect similar ones British Muslims are faced with today. If we manage to do so, the basic contention becomes that if postcolonial literature becomes more socially aware, it can gesture towards a new perspective on the complexity of diasporic identity/ies, one that takes into consideration the unsung affective aspect. At the same time it would also underline the possibilities of challenging seemingly uniform spaces by subverting traditional understandings of the nation and ideas of belonging in Britain, as affective terms are used to re-imagine such concepts. Such an outcome would underline Kureishi's significance as a cultural instigator and hence, as still an influential contributor to contemporary culture, while at the same time providing us with insights into how the need to define oneself became inextricably linked not with race but with religion, as the horrible events we bear witness to today in the Middle East illustrate. In effect, if we are to understand the threat modern-day transnational jihadism and especially a Western-bred one poses to peace and security, we have to go back to the beginning. I argue that a more didactic nature of literature then can -and must- have a significant role in that.

But exactly how can an affective re-imagining of identity in literature have any social meaning and real-life application? In other words, how can fantasy affect reality? Jacques Derrida's notion of desire pertains to a state of lacking (something), so when one eventually obtains that which one did not have but had longed for, desire ceases to be a "lack" and therefore, it is not a desire anymore; by its very nature then, desire is unattainable and unrealisable. It is important to note the connection between desire and society here, as desire is already invested in social formation, which is what creates that interest; in turn, that which creates the sense of lacking. Insofar as I am interested in the way desire actually produces reality, and moving beyond the psychoanalytic view of desire as "lack", for the purposes of this article I put forward a different view based on Deleuze and Guattari's idea in Anti-Oedipus, that "lack" should not be identified with 
desire; rather desire constitutes production in the social field. Deleuze and Guattari analyse the ways in which desire is inextricably intertwined to reality and in particular, to capitalist society, addressing questions pertaining to history, society and human psychology: for them desire, in its anarchic state, produces reality. I specifically read desire then, as a subliminal power that has revolutionary qualities and, therefore, social and political potential, exactly because of its amorphous nature and, therefore, its inability to be categorised. Sara Upstone has argued in "A Question of Black or White" (2008), that if theoretical texts and images such as novels and films, were read in the wake of their direct social engagement with the real world, then the alienation and disaffection of certain communities within a host society might have been addressed earlier; I argue that this can be done specifically if we focus on the affective nature of that social engagement which pertains to questions of belonging. To move this idea further, I attempt a coming together of the theories on desire of Deleuze and Guattari and Brian Massumi; indeed this anarchic state of desire can be explained by bringing the concept of affect into the discussion. In Parables for the Virtual, Brian Massumi argues that affect is a non-conscious experience of intensity, a moment of unformed and unstructured potential which is anarchic and therefore not limited (2002: 30). It is my belief that not despite, but because of this anarchic state of desire, a space of possibilities vis-a-vis identity especially for socially marginalised groups, such as British Muslims, is opened up.

It is true that there is a dialectical process between desire and sexuality in Hanif Kureishi. Based on such a reading of desire then, I read sexuality as not limited to the interaction of female and male roles; rather, I put forward -similarly to my reading of the concept of desire-, a sense of multiplicity that sexuality creates through the production of reality. Sexuality is not, by any means binary in the sense that it is limited to the sexual act between heterosexual gender-opposites. On the contrary, as Deleuze and Guattari argue, "making love is not just becoming as one, or even two, but becoming as a hundred thousand...we always made love with worlds" (1972: 296). If we are to contextualise the aftermath of the dialectical processes such issues are engaged in within historical, societal and political frames, it can be demonstrated that "there are no desiring machines that exist outside the social machines that they form on 58 
a large scale; and no social machines without the desiring machines that inhabit them on a small scale" (1972: 340). Desire is a machine connected to another machine which is the object of desire; thus, to the extent that the desiring production can be socially generated, I attempt to unravel the implications behind its different manifestations within the social realm, focusing on the issue of identity.

What is made evident today is that the manifestation of Islamic fundamentalism -and consequently Islamophobia- emphasises the lack of coherence and unity of the idea of a black community (Desai, 2004: 65) which is why we should examine whether there can be a sense of diasporic identity that pertains to affective terms, stemming from its unformed and unstructured matrix. Hanif Kureishi's preoccupation with issues such as Islamic fundamentalism points to a social aspect of postcolonial literature which embodies a post-ethnic reality that no longer solely pertains to race in addressing questions of belonging. Sara Upstone argues that The Black Album constitutes such "a central text for a more socially aware, materially concerned, and politically engaged postcolonialism" (6). Such a revisiting of the aesthetic and social characteristics of literature based on a retrospective examination of Kureishi's work can provide useful insights for the new nature of the relationship between the two, effectively increasing the importance of desire which rises as a viable alternative to a hitherto largely racially defined identity, all the while moving religious fundamentalism into the spotlight. We are then called to understand the notion of contemporary nation and consequently national identity as a "post-racial space of linkages, synchronicities and equivalences that far surpasses the solipsism of cultural diversity, racial difference or narrow national exclusivity" (McLeod 48). In hindsight then, Kureishi's post-1990 work can be situated within what McLeod has called "contemporary black writing" (2010: 45), a kind of writing that no longer pertains exclusively to race.

\section{"From Fatwa to Jihad"}

The results of our indifference towards the real-world connotations of imaginative pieces of writing culminated in the most horrific way, namely in the active participation of third-generation British immigrants (like, Mohammed Emwazi, the British jihadistexecutioner nicknamed "Jihadi John") in the most brutal regime of our time, the Islamic State of Iraq and the Levant (ISIL). Currently, according to the Economist, around 600 
Britons have gone to fight with the Islamic State and most of them are disillusioned or disturbed when they return. The British government has initiated a de-radicalisation program called Channel, which aims to divert people from extremism. The same process is followed in Denmark, where the thinking behind counselling returning jihadists is that the young men who went to fight in Syria and Iraq were people with few prospects who did not feel welcome in Danish society, a process Kenan Malik agrees with and points out that the same happened in Britain (From Fatwa to Jihad, 2009). I argue that their actions can be attributed -albeit to a point as the process of becoming a fundamentalist is of course a highly complex one to be attributed to a single cause- to a social estrangement from their host society, the traces of which we bore witness to in the early 1990s with the radicalisation in British mosques. It is true that the Thatcher decade left a lot of people angry, discontented and detached; British Muslims more so than others. Thus, as they started seeking a stable sense of identity elsewhere, the nature of a new struggle was underlined and new complexities started to arise. This shift was noticed by Kureishi after doing research in London mosques, and The Black Album was the result of his work. However, not only were Kureishi's new preoccupations not taken seriously but, on the contrary, because he did not deal with Thatcher anymore, certain concerns were raised by critics such as Mahmood Jamal and Ruvani Ranasinha who, in "Dirty Linen" (1988) and Hanif Kureishi (2001) respectively, lamented the aesthetic decline of the author and challenged his political status. It can be argued, however, that even though it might be true that Kureishi's later work did not have the same allure as the aesthetic levels of My Beautiful Laundrette (1985) or The Buddha of Suburbia (1990), the addressing of social issues such as religious violence underlines the shifting importance of religion in questions of belonging in 1990s Britain and indeed, in today's world. Thus, the unravelling of the nature behind the interaction between the aesthetic and the political qualities of a novel, as well as the extent to which this interaction pertains to society at large, must be the scope of such a revisiting.

Even though one cannot argue that Islamic identity politics started with the Rushdie affair, it can be said that the fatwa against the author caused the ensuing rage, feelings of discontent and religious fervour to surface. The fatwa against Salman Rushdie, who was a close friend of the author, shocked Kureishi:

60 
It changed the direction of my writing. Unlike Salman, I had never taken a real interest in Islam. I come from a Muslim family. But they were middle-class - intellectuals, journalists, writers- very anti-clerical. I was an atheist, like Salman, like many Asians of our generation were. I was interested in race, in identity, in mixture, but never in Islam. The fatwa changed all that. I started researching fundamentalism. I started visiting mosques, talking to Islamists (In Malik, 2009, "Kureishi on the Rushdie Affair").

What he found amazed him. He could not understand why these people, born and raised in the West, hated their country so much. In an interview to Mick Brown, he expresses his disgust at what he found, labelling the people there as:

...fascists. Vile. Horrible. You'd want to have a bath afterwards. And the hatred of the West, unspeakable. I mean I hated the West, too, I hated imperialism and all the bad things. But this was a vicious hatred and a deep feeling of violence that was unspeakable. And it's an attack on everything I love - liberal values, free speech, the whole thing (Brown, 2011).

It is understandable then that this more concerned Kureishi who started considering issues that proved to have a tremendous effect on British society in the future. It could be argued that the strong feelings created by his research that clearly imbued his later work, the connotations of which are the aims of this retrospective examination. Kureishi knew that touching upon religious issues was not at all an easy undertaking, but it was a battle he was prepared to fight. Indeed, he believed that his examination of fundamentalism in Britain would create tension, but it was an argument worth having. In an interview with MacCabe, he says:

I don't like fundamentalists, and fundamentalists don't like writers. So you know, there is going to be a kind of animosity between us from the start. But it's an argument worth having and it is worth engaging with the fundamentalists. And I would want them to engage with me too. But it's difficult. But I try (2004: 43).

Such a preoccupation with the contemporary realities of Britain in the 1990s is what led Bart Moore-Gilbert to argue that Kureishi's work can be located particularly within "the condition of England" genre (2002: 110); this statement is true even more so today because the British jihadists are a reflection of the condition of England today. It is true that Kureishi has always been interested in the relationship between the real nature of people and their ideologies -be it cultural, political or religious-, which are props in the identity game, as they all require a measure of conformity. Fundamentalism, with its narrow, monocultural worldview, is nothing if not an extreme ideology. Kureishi looked into it from a political perspective, underlying that his shift of focus from Thatcherism to Islamic fundamentalism was not as disparate as some people may have thought: 
"Islam is rather like Thatcherism. It's an intoxicating force to test yourself against" (Qtd in Eberstadt, 1995: 118). This goes on to testify to the fact that Kureishi shifted his focus after the loss of the political conflict of the 1980s which inspired him and informed his work, towards this new order that was created in the post-Thatcherite years, contextualised by religion. In that, a new space was created, in which conflicts were still created and Kureishi manifested desire in a way so as to compensate for the limiting perspective of Islamic fundamentalism. It is important to note, however, that Kureishi's critique was not directed at religions in general. Rather, he was more preoccupied with the extreme version of religions, which affected the identity formation process in Britain. Indeed, even though he believed that religions are, in reality, illusions, he recognised at the same time their importance:

You can't ask people to give up their religion; that would be absurd. Religions may be illusions, but these are important and profound illusions. But they will modify as they come into contact with other ideas. This is what an effective multiculturalism is: not a superficial exchange of festivals and food, but a robust and committed exchange of ideas - a conflict which is worth enduring,rather than a war (2005: 100).

In effect then, Kureishi reads multiculturalism not in the way it has been celebrated but in a way that is closer to its true nature, as he sees possibilities in religions but only when they come into contact with other ideas, something that fundamentalism, by definition, rejects. One such idea is the manifestation of desire and sexuality in his characters in works such as The Black Album.

During his research for this novel and the short story "My Son the Fanatic" (1994), Kureishi discovered that, along with sexual pleasure, young British fundamentalists had also rejected other kinds of pleasures, so familiar to him. So the question becomes: how can this relationship be transformed by affective terms, so that it does not function unequally? The answer can be found, I argue, in looking at the possibilities that a sense of an affective nature of diasporic identities can offer, especially as a way out of the limits of religious fundamentalism. This is how desire, in the possibilities it offers because of its anarchic state, can produce reality, in offering a "way out" for those thirdgeneration immigrants who refuse to either be totally assimilated by their host nation which would eradicate their identity- or be totally dissociated from it, which can lead to violence, either domestic or international.

62

Indi@logs, Vol 2 2015, pp.55-71, ISSN 2339-8523 


\section{Revisiting The Black Album}

Kureishi's The Black Album (1995) engages directly with the Rushdie Affair, even though Salman Rushdie is not named in the book at all. The issue of Islamic fundamentalism is looked at through the lens of desire and sexuality, and as we identify the implications behind their interaction, we realise Kureishi's significance in keeping up with -or, some might argue, in being ahead of- the times. Indeed, it is argued that the dilemma Shahid Hassan (the protagonist) is faced with and the ramifications of his choice, reflect the choice many third-generation immigrants face today vis-a-vis questions of belonging and the dangers of being assimilated in the rubric of Islamic fundamentalism, which inevitably leads to violence. The Black Album follows Shahid's oscillating desire for Riaz, the leader of a local Islamist group, and for Deedee Osgood, his sexually liberated teacher. It narrates an intersection of the social realm and especially its rising religious fundamentalism and sexual desire. Sex, drugs and pornography are paraded for the audience through the relationship between Shahid and Deedee. Their relationship testifies to how Shahid accepts the fluid nature not only of his own self but of society at large, through his own erotic alteration. The conflict comes with the juxtaposition of sexual abstinence, in Riaz's group, and a hedonistic lifestyle in Deedee, with Shahid caught between them. He is drawn to both of them and the novel culminates in what is Shahid's final moment of decision, which comes when Riaz's group organises a burning of Rushdie's book The Satanic Verses (albeit not named) on campus. In this scene, Kureishi shows the final clash of sexual expression and religious violence, as I maintain that the two are, in fact, much more correlated than we may have thought. Abstinence from sexual pleasure, advocated by fundamentalists, can lead the repressed to violence while sexual expression can be seen as an alternative system to religious, limiting views of the world. And it seems that the burning of the book is a failure of imagination instead of a triumph of religion in that it is not Islam that emerges victorious from that scene; rather it is a testimony to the complex nature between religious violence and desire.

At first, Shahid is torn, trying to find his identity between the pleasures afforded to him by the culture he lives in, embodied in the sexually adventurous relationship with Deedee, and the religious fervour and denial of pleasure by the charismatic Riaz. Riaz 
Al-Hussain, the strong leader of the Islamic student group, fascinates Shahid, as he has a new sense of identity to offer to the troubled young man, much like second- and thirdgeneration Muslim immigrants found a stable sense of identity in religious fundamentalism, something that can be marked down as a failure of their host society to offer the same:

These days everyone was insisting on their identity, coming out as a man, woman, gay, black, Jew - brandishing whichever features they could claim, as if without a tag they wouldn't be human. Shahid, too, wanted to belong to his people (1995: 34).

In sharp contrast to the strict Islamic way of life, Kureishi positions the hedonistic and fetishistic Deedee, whose sexual connection with her student comes into clash with Islamic beliefs. There are two contrasting definitions of ideology here, a "coherent body of ideas that legitimates political rule... [and] a form of thought or identity springing not from the ruling elite, but rather from a section of the populace" (Upstone, 2001). Sara Upstone argues that what unites them is their need for defining a context within which individuals locate themselves and their relationship to society. Religion denies pleasure to its disciples in exchange for a perceived stable sense of identity. However, Kureishi believed that such a process of "Islamisation", of re-explaining and repossessing Islam for selfish purposes, did not build any hospitals, schools, houses, nor did it clean water and install electricity. But it entailed a sense of direction and identity:

Moral mission[s] and the over-emphasis on dogma and punishment resulted in the kind of strengthening of the repressive, militaristic and nationalistically aggressive state seen all over the world in the authoritarian 1980s (2004: 26).

Consequently, this strong sense of identity fundamentalists believed they had found and the strengthening of the repressive stance of the state collided and led to religious violence a few years later as much as it started the violent process whose results we witness today.

The two worlds clash violently by the end of the novel, which also gestures towards the past burdening on the present. For Kureishi, tradition seems to create a sense of false intimacy:

I compared the collective hierarchy of the family and the performance of my family's circle with my feckless, rather rootless life in London, in what was called the "inner city". There I lived alone, and lacked any long connection with anything...People came and went. There was much false intimacy and forced friendship. People didn't take responsibility for each other. Many of my friends...didn't merely want to reproduce the 
old patterns of living. The future was to be determined by choice and reason, not by custom (1996: 38).

Indeed, for him, the burden of the past disguised as tradition can be held responsible for people's current view of society, which, in turn, can bring about a new wave of essentialist choices. In Kenan Malik's From Fatwa to Jihad, Anandi Ramamurthy argues that the formation of the Asian Youth Movement in Bradford was an expression of the failure of "white" left organisations in Britain to effectively address the issues that affected Asian communities (2009: 52). We see a similar situation in Kureishi's My Beautiful Laundrette (1985) where the character of the protagonist's father, is an embodiment and a critique of the failed Left, which did not provide a viable alternative to Thatcherite policies. So, it seems that we can connect those two major events in the 1980s and today, namely the fatwa against Rushdie and the Jihad today with the alienation that young British Muslims felt, as the past -in the form of "the religion of our fatherland"- weighted on the present, affecting many of them. At the same time, we need to note that the failed Left could not offer a solution to right-wing identity policies which favoured heteronormative masculinity, racism and militancy, excluding thus from the national rubric people and communities such as homosexuals, Muslims, blacks etc. Naturally, such processes led to the alienation of these communities which in turn, led to violence. Kenan Malik reminds us of the Mullah Boys of Beeston, a gang led by two of the people who would later carry out the London bombings in 2005 (Mohammed Sidique Khan and Shehzad Tanweer), arguing that those boys were consumed by rage, a loss of identity and getting caught between "no cultures", having found the expression for their personal alienation in the spurious legitimacy of extremism (Gazi, 2009). It seems then that radical British Muslims got -albeit inadvertently- entangled in a Manichean position of "us and them" and "good and evil" -a situation that reflects the contemporary one- where pleasure was banned and the consequences of this were grave. And this was an issue that troubled Kureishi:

It perplexed me that young people, brought up in secular Britain, would turn to a form of belief that denied them the pleasures of the society in which they lived... Why did they wish to maintain such a tantalizing relation to their own enjoyment, keeping it so fervently in mind, only to deny it? Or was this Puritanism a kind of rebellion, a brave refusal of the order of the age - an oversexualized but sterile society? (2005: 23).

This relationship between past and present, read within the context of pleasure, seems to inform the ending of The Black Album. I argue that, just as Shahid, through choosing 
desire over religion, is able to dictate the path towards his own future, escaping essentialist choices, the same can be said about the choice British Muslims face today. Thus, it seems that sexual pleasure and played-out desires within the historical context created by the clash of past and present, can actually generate reality. After all, the entire socio-political field can be seen as a product of desire which is historically determined (Deleuze and Guattari, 1972: 18). It can be argued then that this realitygenerating sense of desire can grant freedom, pointing towards a path which MooreGilbert positions "between apoliticism and militancy" (2002: 115). As he is being translated from one culture to the other, Shahid wants recognition and acceptance from South Asians and British alike. In the end it all comes down to a sense of choice of where to belong. Shahid does not accept the traditional mentality as this would automatically impose restrictions and limitations to his life, as he would have to adhere to the essentialist binaries that come with it. This refusal has a twofold meaning, the first of which is the uneasiness of the members of the South Asian diasporic community in Britain with succumbing to limitations passed down from their colonial past. Secondly, it reveals Kureishi's vision for a future society which comprises all polycultural aspects of its population, a vision not shared by today's British fundamentalists. Desire then enables characters to avoid their entanglement into the ageold either-or position and shows that there is another way in their quest for a place in society, in that it enables them to escape the burden of tradition. It seems then that Kureishi rejects the old views in favour of a view of a future for Britain without imposed limitations and without allowing the past to weigh down the present, encouraging a cross-communal and transcultural understanding in the process.

In the end, Shahid's choice is a rejection of traditional thinking based on race or nationality, in exchange for his sexual life with Deedee. One could argue that Kureishi does not explore Shahid as such; rather, he re-inscribes him and the sexual manifestations of his identity, pointing to a new generation of immigrants who could escape tradition as a burden. He re-inscribes Shahid as someone who, not despite of, but because of his impossible position between cultures and identities, is able to dictate his own terms of belonging. Such a choice suggests alternative modes of belonging defined by cultural diversity rather than cultural (or racial) uniformity. I argue then that it is 66 
possible for British Muslims to rethink their sense of belonging today in affective terms which would offer hope for the future as imagination is not consumed by fundamentalism anymore:

The antidote to Puritanism isn't licentiousness, but the recognition of what goes on inside human beings...Fundamentalism is dictatorship of the mind, but a lived culture is an exploration, and represents our endless curiosity about our own strangeness and impossible sexuality: wisdom is more important than doctrine; doubt more important than certainty. Fundamentalism implies the failure of our most significant attribute, our imagination (The Black Album 283).

Brian Massumi is brought to mind here, as he reads affect as "a suspension of affectreaction circuits and linear temporality in a sink of what might be called passion" (2002: 29). This suspension constitutes a temporary solution to the impossible position of having to choose sides, as Shahid finds himself within a temporal and liminal space. What is more, Marco Abel has argued that affect is not defined as a thought, but rather as something associated with sentiment and feeling, and as something that lacks rationality (2007: 11). Thus, Shahid's sexual, cultural and religious experimentation and the corresponding relevant aspects of identity, go on to testify to the need of the individual to choose a fluid identity and an ever-changing self as opposed to the strict limits Muslim fundamentalists define themselves in, which drives them to fight their host society and its values. Kureishi's elucidation is to present identity as a process, as having an unstable and ever-changing nature, which allows his characters, and by association himself and the members of the diasporic community, not to choose sides, a process that Bart Moore-Gilbert has termed a "third way out" (2002: 115), as Shahid chooses passion over politics. This is a choice, indeed, which people like modern British fundamentalists fighting in the Middle East clearly did not make. On the contrary and in hindsight, Riaz can be read as the fictional representation of people like "Jihadi John" (even though it cannot be said that he represents or symbolises all fundamentalists) who force people to face harsh choices. In the wake of this clash between secularism, sexuality and religion, desire functions as a counterbalance to the political nature of religion, as it is understood by fundamentalism, thus not only being elevated, but also enabling the characters to escape the essentialist either/or position. And it is the implications of the violent scene at the end of the book, with the burning of the book at the university campus, that transcend the primary subject matter, as the true "practice and pedagogical force" (Abel, 2007: xiv) of literary images is unveiled. 
Attending to the effects provoked by the reality of this violent image in literature, one has to think of these images in affective terms, as Abel argues, rather than "addressing them on the level of their representational quality, as is commonly done" (2007: xiv).

\section{Radical Islam and Imagination}

Kureishi has said that "Muslim fundamentalism has always seemed to me to be profoundly wrong, unnecessarily restrictive and frequently cruel. But there are reasons for its revival...it is...degrading to be a victim in your own country. If you feel excluded, it might be tempting to exclude others" (1994: xi-xii). This sums up perfectly the reasons behind what is happening today with ISIL and British fundamentalists. Because they feel excluded from the western type of life - just like their parents and their grandparents in the 1990s and 1980s-, they are susceptible to resort to violence in order to exclude others. However, this article has argued that if we start thinking about identity in affective terms and, given that such an examination can lead to a generating of reality, then the very real violent issues associated with the discontents of religion and questions of belonging in Britain today, can be addressed. It seems then that desire is transformed into a positive, productive force, especially in terms of subjectivity and belonging for members of the Muslim South Asian diasporic community in Britain and British society as a whole, as opposed to the limiting function of Islamic fundamentalism. Such a reading gestures towards a creation of a space of possibilities which, in turn, can lead to new ways of imagining identity and subjectivity.

As long as this is not done, imagination and all its trajectories will continue to lose the battle against fundamentalism. As Faisal Gazi argues in an article in The Guardian, the Muhammad cartoons scandal and Random House's decision to retract the publication of Sherry Jones's novel The Jewel of Medina after an online thread on a discussion forum are just two instances of how the grievance of radical Islam is winning the battle against Enlightenment values (2009). Random House's statement reads that "not only the publication of this book might be offensive to some in the Muslim community, but also it could incite acts of violence by a small, radical segment" (2008). It seems then that the threat of violence -albeit an indirect one- and fear have damaged imagination. This alienated "small, radical segment" is exactly the by-product of the processes started in 68 
the 1980s and 1990s, as has been argued in the present article. Thus, reading identity in affective terms can be a solution to that problem, in that it offers a new way of thinking, pertaining to the social aspect of literature produced in the $1980 \mathrm{~s}$, a similar era of discontents as today, when the seeds of contemporary violence were planted. I argue that novels such as The Black Album are first and foremost "Zeitgeist" texts, a characteristic that goes beyond their aesthetic value. Indeed, they are literary works about the spirit of the times, engaging directly with very serious, contemporary problems such as Islamic fundamentalism. Had such literary production pertaining to affective issues been viewed not only in its aesthetic importance, but within a social context and had it been understood that such works could have had a profound effect on the grim reality we are facing today, we may have anticipated the alienation of certain groups that led to religious violence. Salman Rushdie in The Satanic Verses has said that "a poet's work is to name the unnameable, to point at frauds, to take sides, start arguments, shape the world, and stop it from going to sleep. And if rivers of blood flow from the cuts his verses inflict, then they will nourish him" (1988: 97). Similarly, Kureishi, defending such a scope of the text and talking about the role of the artist, asks: "But don't writers try to explain genocide and that kind of thing? Novels are like a picture of life" (1995: 21). It seems then that literature, above and beyond its aesthetic value, has a very significant role to play in issues such as identity, estrangement and feelings of discontent especially among members of the Diaspora, as exemplified by its power to affect reality.

\section{WORKS CITED}

ABel, Marco (2007). Violent Affect: Literature, Cinema and Critique after Representation. Lincoln: University of Nebraska.

Amitava, Kumar (2001). "A Bang and a Whimper: A Conversation with Hanif Kureishi." Transition 10:4: 114-131.

Brown, MicK (2011). “A Life Laid Bare.” Interview with Hanif Kureishi. Telegraph http://www.telegraph.co.uk/culture/books/3671392/Hanif-Kureishi-A-life-laidbare.html

Deleuze, Gilles And Guattari, FeliX (1972). Anti-Oedipus: Capitalism and Schizophrenia. London: Penguin. 
Desai, Jigna (2004). Beyond Bollywood: The Cultural Politics of South Asian Diasporic Film. New York: Routledge.

EBerstadt, FernandA (1995). “Rebel, Rebel.” The New Yorker, 71: 25: 117-120.

GAZI, FAISAL (2009). "Britain Since the Fatwa". The Guardian, Online version, 14 April.

http:/www.theguardian.com/commentisfree/belief/2009/apr/14/religion-islam

GiddA, MirREN (2014). "No Place Like Home: What to Do When Jihadists

Return”. 18 Nov 2014, BBC News.

http://www.bbc.com/news/world-middle-east-29725116

KUREISHI, HANIF (1996). "The Rainbow Sign", in My Beautiful Laundrette and Other

Writings. London: Faber and Faber, 1985.

(1990). The Buddha of Suburbia. London: Faber and Faber.

(1995). The Black Album. London: Faber and Faber.

(1997). My Son the Fanatic. London: Faber and Faber.

(2005). The Word and the Bomb. London: Faber and Faber.

MacCABe, Colin (2004). "Hanif Kureishi on London.” Critical Quarterly 41.3: 37-56.

MAHMOOD, JAMAL (1988). "Dirty Linen." in Black Film, British Cinema, ICA

Documents, London: British Film Institute, 21-22.

Malik, Kenan (2009). From Fatwa to Jihad: The Rushdie Affair and Its Legacy.

London: Atlantic.

(2009). "Kureishi on the Rushdie Affair." In Prospect, April 2009.

Massumi, Brian (2002). Parables for the Virtual: Movement, Affect, Sensation.

Durham: Duke University Press.

MCLeOD, JoHn (2010). "Extra Dimensions, New Routines: Contemporary Black

Writing of Britain.” Wasafiri 25.4: 45-52.

MoOre-Gilbert, BART (2002). Hanif Kureishi. Manchester: Manchester University Press.

Ranasinha, RuVAni (2001). Hanif Kureishi. Tavistock: Northcote House Publishers.

Rushdie, SALman (1998). The Satanic Verses. London: Vintage Books, 1988.

ThE ECONOMIST (2014). “Turning them Around”. In Bridge over Troubled Water. Nov,

15. http://www.economist.com/news/britain/21632628-britain-becoming-moresophisticated-dealing-returning-fighters-turning-them-around 
The RANDOM House Publishing Group (2008). Statement on the Jewel of Medina.

http://www.randomhouse.com/rhpg/medinaletter.html

UPSTONE, SARA (2001). “A Question of Black or White: Returning to Hanif Kureishi’s The Black Album." Postcolonial Text 4.1, 2008.

http://www.postcolonial.org/index.php/pct/article/download/679/518 